\title{
ANALYSIS OF POLY(A) + RNA DISTRIBUTION DURING MAIZE SOMATIC EMBRYOGENESIS USING DIGOXIGENATED OLIGO-dT PROBES
}

\author{
R. BIMAL ${ }^{1}$, F.B.F. BRONSEMA, M.T.M. WILLEMSE and J.H.N. SCHEL \\ Department of Plant Cytology and Morphology, \\ Wageningen Agricultural University, \\ Arboretumlaan 4, 6703 BD Wageningen, The Netherlands
}

\begin{abstract}
The pattern of total transcription activity in terms of steady state levels of poly $(\mathrm{A})+$ containing mRNA during callus initiation and somatic embryogenesis in a high (A188) and a low (A632) embryogenic line of maize was analyzed using digoxigenin labelled oligo-dT probes. A gradual increase and a preferential accumulation of label was observed in both lines, differing temporally up to 4 days in culture. In the A188 line of maize the callus gave rise to somatic embryos. The globular embryos showed less label than the callus; this labelling was mostly present in the basal part of the embryos. At a later stage upper embryogenic and lower non-embryogenic layers were observed in the A188 callus, showing conspicuous differences in the amount of label. In the late globular stage the poly(A)+ RNA signals were seen all over the embryo but at the junction of the suspensor and the callus tissue no label was observed.
\end{abstract}

KEY WORDS: Zea mays L., histochemistry, embryogenesis, RNA synthesis.

\section{INTRODUCTION}

Somatic embryogenesis in plants, including maize, besides offering an excellent system to study early development, also has considerable commercial value. Therefore, many aspects already have been investigated, last years focussing on differential gene expression and molecular markers for embryogenesis (see e.g. De Jong et al., 1993). Although these approaches are of great value, not only the expression of specific genes during callus initiation and induction of embryogenesis is important, but also insight in the overall reprogramming of mRNA synthesis. This approach is emphasized e.g. by Raghavan (1981) who studied mRNA synthesis during pollen embryogenesis in Hyoscyamus using tritiated poly-U probes for in situ hybridization. More recently, Chandra Sekhar and Williams (1992) have studied the in situ localization of poly(A)+RNA during pollen development in Nicotiana using non-radioactive digoxigenated oligo-dT probes. We have adapted this sensitive and fast method to compare unprocessed mRNA distribution during early stages of embryogenic and non-embryogenic callus development in maize.

\section{MATERIALS AND METHODS}

\section{Plant material and culture conditions.}

Zea mays plants of both inbred lines A188 (high embryogenic response) and A632 (low embryogenic response) were

${ }^{1}$ present address: Department of Botany, Bihar University, Muzaffarpur, 842001, India

Correspondence to: J.H.N. Schel grown in a climate chamber with $16 \mathrm{~h}$ light at $24^{\circ} \mathrm{C}$ and $8 \mathrm{~h}$ dark at $20^{\circ} \mathrm{C}$ at a relative humidity of $70 \%$. Light was provided by Philips 50W/84 HF fluorescent tubes with an intensity of $50 \mathrm{~W} / \mathrm{m}^{2}$. Additional red light was provided by Philinea lights. Immature zygotic embryos with a length between 1 and $2 \mathrm{~mm}$ were excised 11 days after pollination of the cobs. The embryos were transferred into Petri dishes with solidified N6 medium (Chu et al., 1975), containing $0.7 \%$ agar, $2 \mathrm{mg} / \mathrm{L}$ 2,4-D, $20 \mathrm{mM} \mathrm{L}$-proline, $200 \mathrm{mg} / \mathrm{L}$ casein hydrolysate and $2 \%$ sucrose. They were placed with the embryo axis in contact with the medium. Callus initiation took place in the dark at $25^{\circ} \pm 1^{\circ} \mathrm{C}$. For more details, see Fransz and Schel 1991a, 1991b.

\section{Histochemistry.}

With 2 day intervals, samples were fixed in $1 \%$ glutardialdehyde in $0.1 \mathrm{M}$ cacodylate buffer ( $\mathrm{pH} 7.2$ ) for 3 hours, dehydrated in a graded series of ethanol, infiltrated with xylol and finally embedded in paraffin. Semithin $(5 \mu \mathrm{m})$ sections were made and mounted on organosilane-coated slides. The slides were dried overnight at $40^{\circ} \mathrm{C}$. After that, they were incubated with digoxigenin-labelled oligo-dT probes, which were prepared from a terminal transferase kit (Boehringer Mannheim, Germany). The hybridization regions were detected using an anti-digoxigenin antibody conjugated with alkaline phosphatase (Boehringer Mannheim, Germany). Alkaline phosphatase activity was indicated by a reaction with NBT (nitroblue tetrazolium) and BCIP (5-bromo-4-chloro-3-indolyl

\section{Abbreviations}

BCIP - 5-bromo-4-chloro-3-indolylphosphate; 2,4D - 2,4 dichlorophenoxy acetic acid; DIG - digoxigenin; NBT - nitroblue tetrazolium 

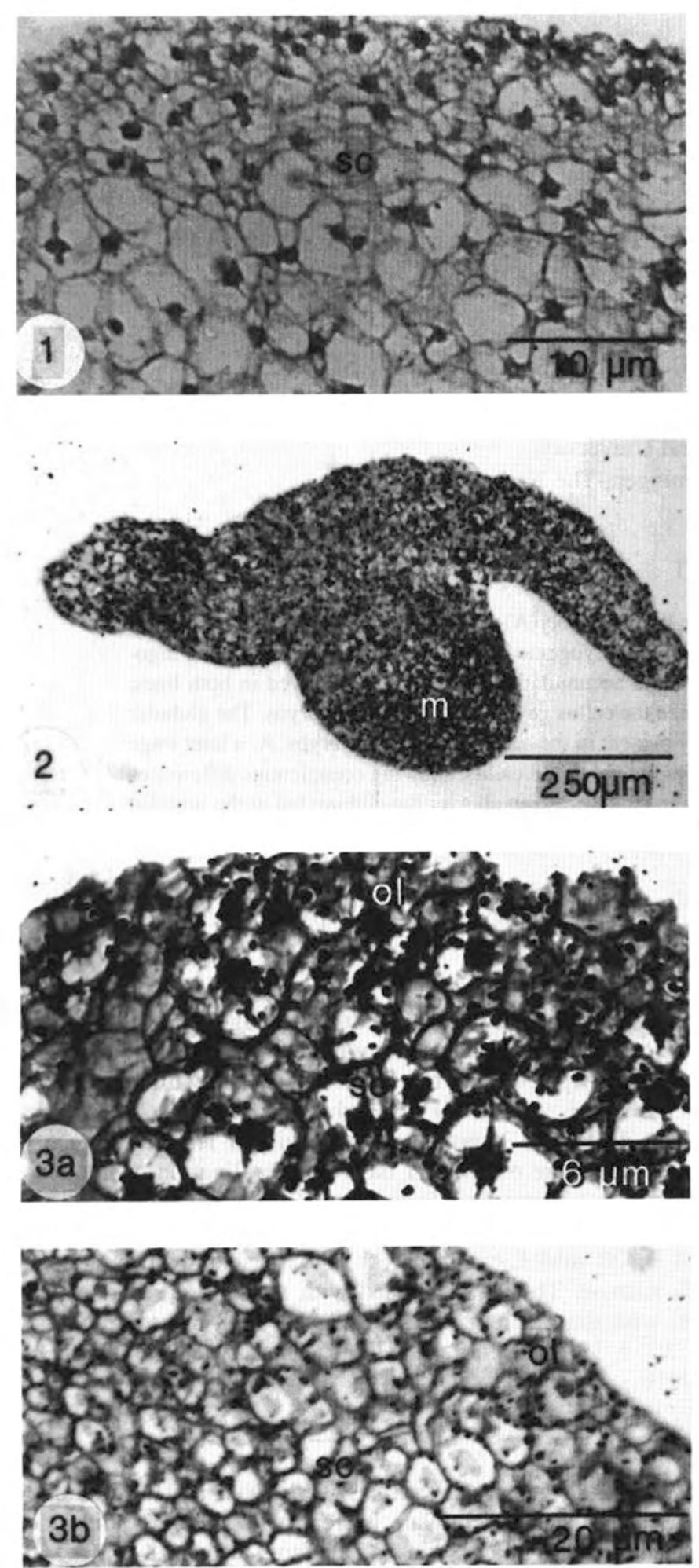

Figs 1-4. In situ hybridization of DIG-labelled poly(A) control probe or oligo-dT probes with poly(A)+RNA in sections of maize. Fig. 1 . Section of a maize zygotic embryo $(\mathrm{t}=2)$ hybridized with the control probe. Fig. 2. Zygotic embryo of $\mathrm{A} 188(\mathrm{t}=0)$ showing more label in the meristematic zone. Fig. 3a. Accumulation of poly(A)+RNA sig nals in the scutellum in A188 (t=2). Fig. 3b. Zygotic embryo of A632 $(\mathrm{t}=2)$ showing no preferential localization of signals in the scutellum. Fig. 4a. A188 culture $(\mathrm{t}=4)$ showing a conspicuous increase in signal. Highly vacuolated cells have very few or no label (arrows). Fig. 4b. Embryogenic unit of A188 callus $(\mathrm{t}=4)$ surrounded by a cell layer having few or no label. Fig. 4c. Increase in label in the scutellar part of an A632 embryo (t=4). Fig. 4d. Less label is present in the basal part of the A632 embryo ( $t=4)$.

bp, basal part; m, meristem; ol, outer layer; sc, scutellum.
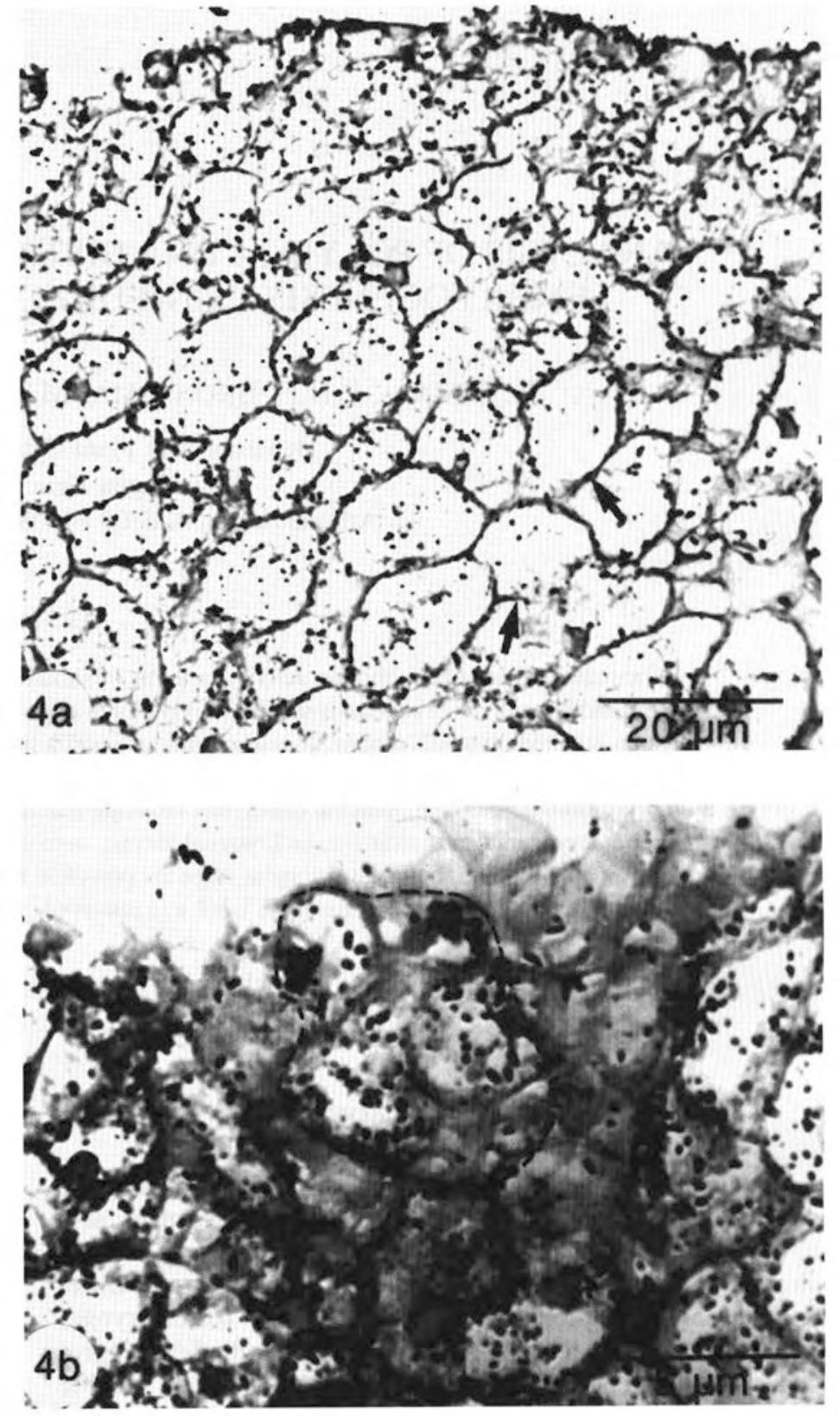

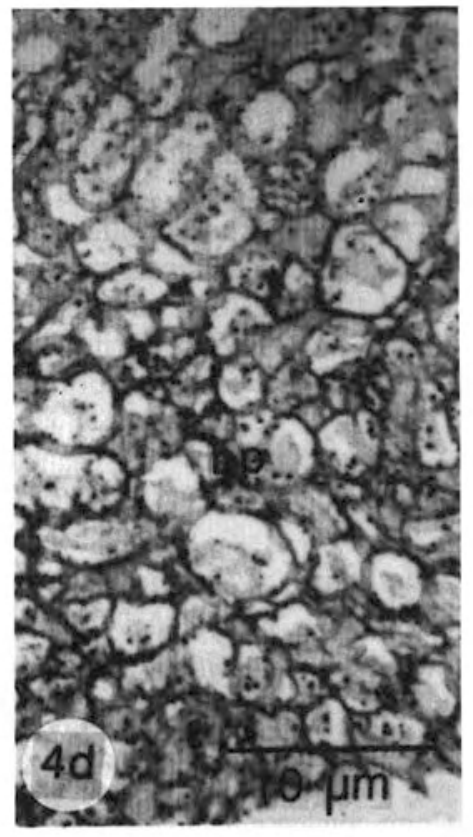


phosphate), giving rise to blue precipitates. After these histochemical treatments, the sections were washed twice in distilled water, air dried and mounted in Depex. For a more detailed description of the procedures, see Bimal et al. (1995).

\section{RESULTS}

Sections of cultured zygotic maize embryos, hybridized with DIG-labelled poly(A) as a control, did not show any label (Fig. 1). After hybridization with the oligo-dT probe at the onset of culture $(t=0)$ the embryogenic line A188 differed from the badly regenerating line A632 in three aspects: i. presence of more label all over the embryo, ii. concentration of more label in the meristematic zone, and iii. a rather uniform localization of signals in the scutellar region (Fig. 2).

Sections of A188 embryos after 2 days in culture $(t=2)$ showed an overall increase in the amount of label as compared with $\mathrm{t}=0$. Especially the outer cell layers of the scutellum showed a high poly(A)+RNA accumulation (Fig. 3a). Most of the label was distributed over the cytoplasm. The $t=2$ culture stage of the non-embryogenic line A632 showed only a slight increase in label as compared with $\mathrm{t}=0$ (Fig. 3b). There was no preferential localization of label at this stage of development in the A632 line as was seen in the scutellum region of A188.

In a 4 days old culture of A188 there was a conspicuous increase in poly(A)+RNA binding signals, which were more or less uniformly distributed throughout. However, highly vacuo-

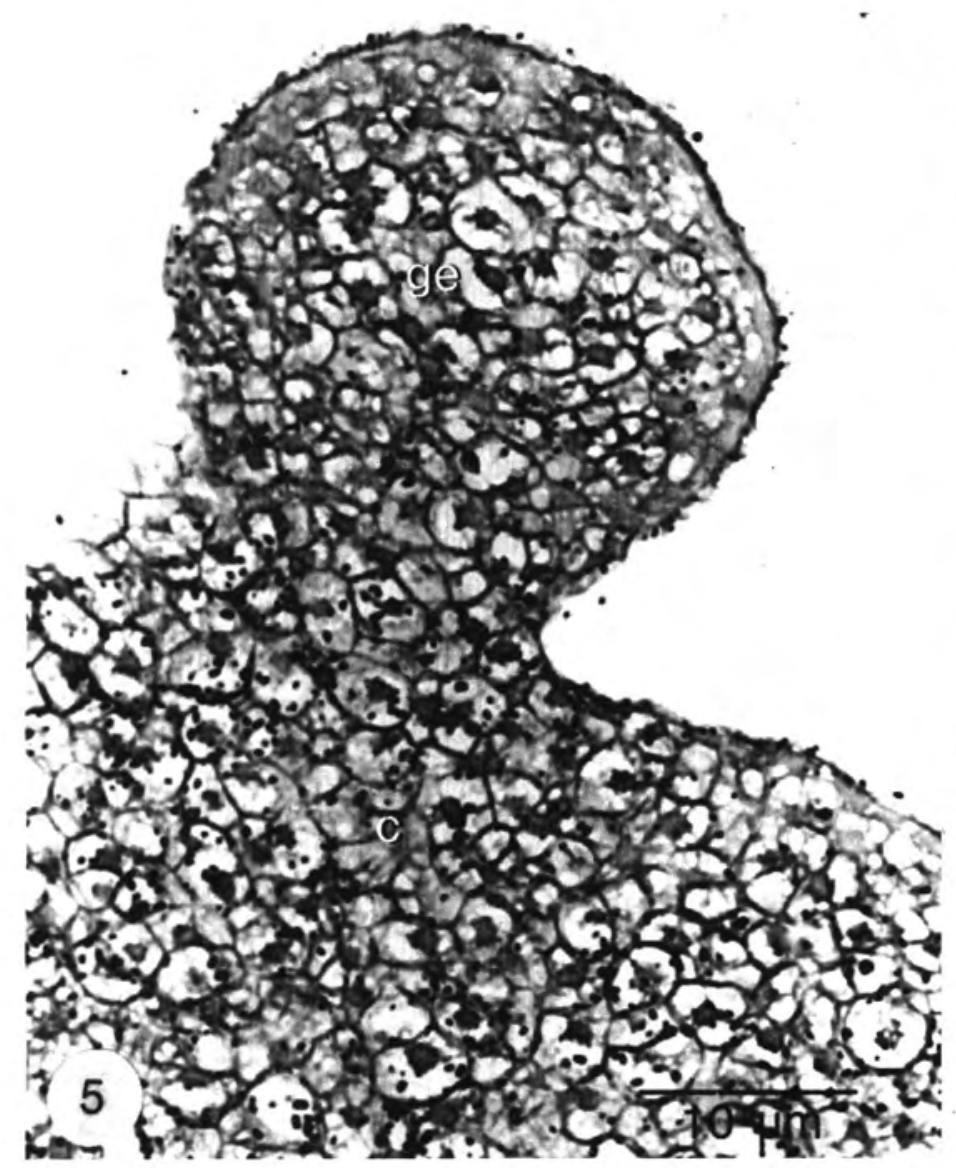

Figs 5-7. In situ hybridization of DIG-labelled oligo-dT probes during somatic embryogenesis in A188. Fig. 5. A globular embryo $(\mathrm{t}=6)$ showing less label than the callus. Fig. 6. Callus $(t=10)$ showing more label in the upper cell layers (embryogenic zone). Fig. 7. Large globular cell clusters at the periphery of the embryogenic zone in A188 $(t=12)$ contain more label than the callus. c, callus; ge, globular embryo.

Fig. 8. A more organized somatic embryo showing the root meristem and a high level of label at the prospective site of the shoot apex (arrow).

c, callus; ge, globular embryo; rm, root meristem; s, suspensor.
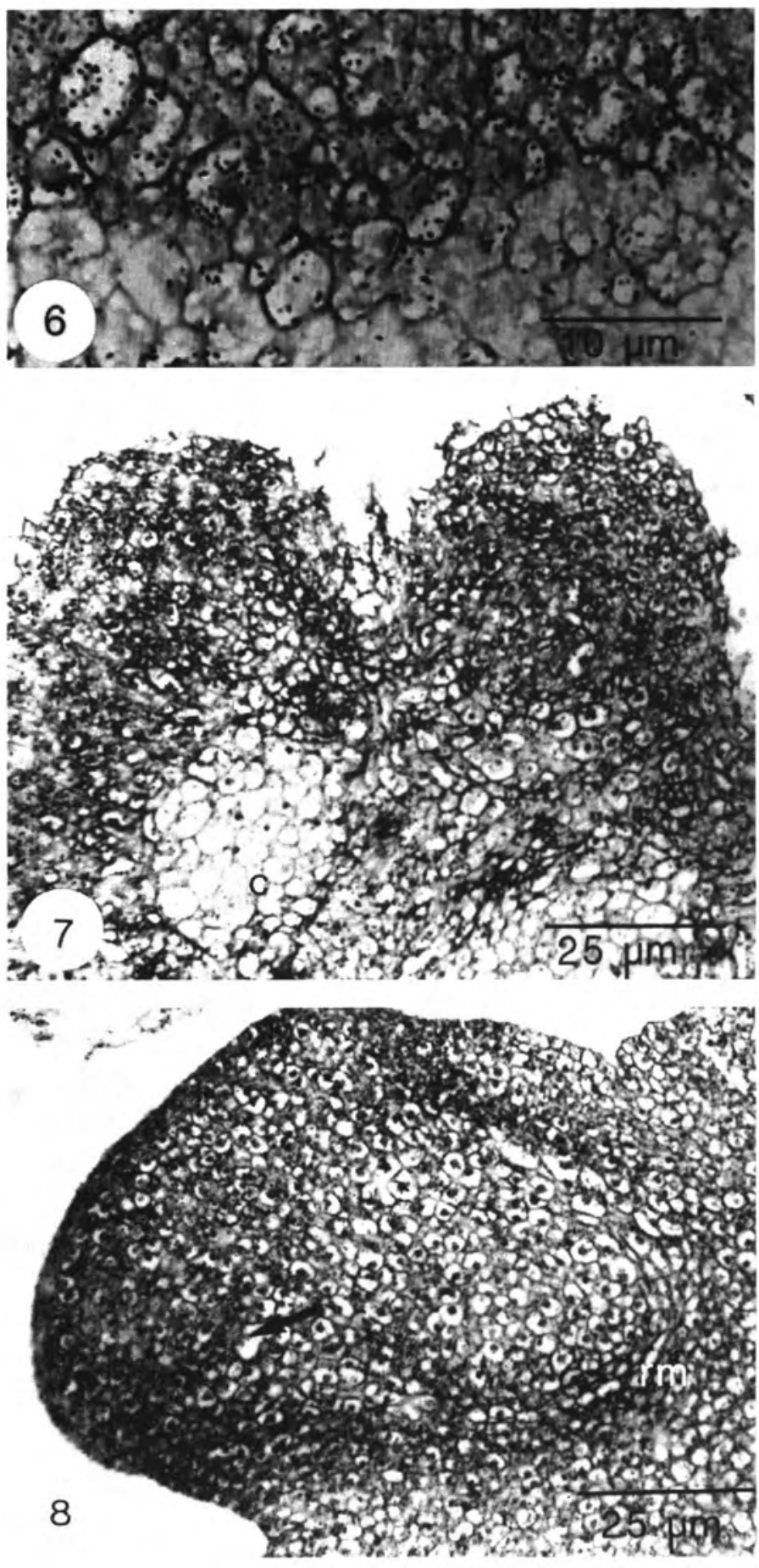
lated cells either showed very few label over the cytoplasm along the cell wall or the labelling was absent in such cells (Fig. 4a). Incidentally a group of cells, probably an embryogenic unit, was observed at the surface of the scutellar region (Fig. 4b). The cells surrounding this cell group contained either very few or no label. There was an increase in label as compared with the $\mathrm{t}=2$ culture. In the non-embryogenic line A632 there was also an increase of label at 4 days of culture as compared with $t=2$. More label was observed in the scutellar part of the embryo than in the basal part (Figs 4c, d).

At 6 days in culture small globular somatic embryos were observed in the A188 line (Fig. 5). In the globular structures the amount of label was less than in the callus cells. The label was mostly present in the cells of the lower part of the embryo connected with the callus. However, the callus cells adjoining the globular structures showed more accumulation of poly(A)+RNA signals. In the A632 line, the callus cells at $t=6$ had more label than at $\mathrm{t}=4$. No globular embryo stages were observed, which agrees with the non-embryogenic character of this line.

At 10 days in culture the callus of the embryogenic line A188 exhibited two zones of accumulation of poly(A)+RNA signals. The upper zone, which is supposed to be embryogenic and to produce somatic embryos, contained more label than the lower basal part of the callus (Fig. 6). Such a phenomenon was not observed in the A632 line.

After 12 days in culture, on the A188 callus somatic embryos of various shapes, representing different developmental stages, were observed. Large globular cell clusters at the periphery of the embryogenic zone, consisting of small, mostly non-vacuolated cells, showed more label and were separated from the rest of the callus by vacuolated cells having comparatively less label (Fig. 7). The more developed oblong or pear-shaped somatic embryos contained an overall accumulation of label. In late globular stages, with a suspensor present, poly(A)+RNA label was observed all over the somatic embryo, but the upper part contained more label than the lower part. At the junction of the suspensor and the callus, there was an absence of signal. In a more organized embryo (Fig. 8) the root apex was present showing more label towards the outer side, while the central core of cells on the inner side of the root apex was vacuolated and showed less label. Further, in the upper part a high concentration of label could be observed, which probably represents the prospective site of shoot apex formation.

\section{DISCUSSION}

The presence of more poly(A)+RNA label in the embryogenic line (A188) and the difference between A188 and A632 in poly(A)+RNA distribution at $\mathrm{t}=0$ seems to be genotypic. The occurrence of more vacuolated cells might be one of the reasons for less signal in the A632 line. In both maize lines, the poly(A)+RNA binding signals at $\mathrm{t}=0$ might indicate the presence of messengers for polypeptides corresponding to housekeeping genes (Kamalay and Goldberg, 1980; Bertrand-Garcia et al., 1992).

The gradual increase in poly(A)+RNA, its accumulation in the scutellar region in the $t=2$ culture and the further increase in the number of label in the $t=4$ culture of $A 188$ is interesting. It might represent transcripts responsible for extracelluar proteins which are enhanced during carrot somatic embryogenesis in the dermal tissues (Sterk et al., 1991). Sung and Okimoto (1981, 1983), Chen and Luthe (1987) and Stirn and Ja- cobsen (1987) have also observed polypeptides specific for embryogenic growth in carrot, rice and pea respectively. The increase in poly $(\mathrm{A})+$ containing $\mathrm{mRNA}$ during $\mathrm{t}=2$ and $\mathrm{t}=4$ might also be related to the biphasic model of early callus formation as proposed by Fransz et al. (1990) for cultured maize embryos.

A comparatively less but gradual increase in poly(A)+RNA in $t=2$ and $t=4$ cultures of the non-embryogenic line (A632) also points to active mRNA synthesis. The preferential accumulation of label in the scutellum in the $t=4$ cultures in A632 seems to represent messages for callus initiation, although in A188 this was observed in $t=2$ cultures. In the $t=4$ culture of A188 the embryogenic groups with labels were separated by a cell layer having very few or no labels indicating a kind of isolation or imposition of stress which may be a pre-requisite for the acquisition of embryogenic potentiality. Fransz et al. (1991a) also observed physiological isolation of such embryogenic groups in the A188 line.

In $t=6$ cultures of $\mathrm{A} 188$ globular embryoids are observed, showing a differential distribution of poly(A)+RNA. The lower basal part of globular embryoids has more label. This suggests the presence of informational molecules involved in proper nurturing of the globular embryoids. Wilde et al. (1988) studied the mRNA population of proembryogenic masses (PEM), embryogenic and mature tissues in carrot and they found 21 polypeptides specific for PEMs and embryogenic tissues.

Significantly, in $t=10$ cultures of the embryogenic line A188 the upper embryogenic and the lower somatic zone can be distinguished based on the presence of more label in the embryogenic zone than in the somatic zone. It seems that all the cells of the upper embryogenic zone have informational molecules conductive to the development of somatic embryos. In $\mathrm{t}=12$ cultures of $\mathrm{A} 188$, somatic embryos of different developmental stages, showing progressive increase in the poly(A)+RNA signals , are observed. Wilde et al. (1988) observed that cDNAs Dc3, Dc5 and Dc13 increase in abundance during somatic embryogenesis in carrot.

The embryogenic or meristematic cell clusters originating at the periphery of the embryogenic zone show more label than the callus cells. The presence of more poly(A)+RNA signals, possibly representing late embryogenesis abundant (LEA) gene transcripts. (Wurtele et al., 1991; Zimmerman, 1993), all over the somatic embryos in oblong or late globular stages probably suggests a high and coordinated mitotic activity among different cells of the embryoid to keep pace with the growth. It also could indicate a state of readiness for organogenesis.

In the late globular stage the presence of less label in the lower basal part and decrease or loss of informational molecules at the place of attachment of the suspensor and the callus might suggest a kind of strained source-sink relationship or maybe a stress signal, triggering the somatic embryos to develop their own root meristem. It also might indicate the prospective site of detachment of the embryoid from the mother callus.

In more developed and organized embryos the upper part has more poly(A)+RNA label, representing the prospective shoot apex while the cells outside the newly formed root meristem have more labels than the cells on the innerside of the root meristem . A gradual accumulation of EMB-1 LEA gene mRNA has been shown as somatic embryogenesis proceeds further from globular to late developmental stages predominantly over peripheral regions of the embryo, indicating initiation of polarity (Wurtele et al., 1991). 
In the past, many, mostly biochemical, studies have been made to register metabolic changes during somatic embryogenesis (e.g . Montague et al., 1978; Fujimura et al., 1980; Sengupta and Raghavan, 1980; Ashihara et al., 1981; Sung et al., 1981). We conclude that the use of oligo-dT probes to localize poly (A)+RNA is an additional way to follow stage and genotype specific differences in gene expression.

\section{ACKNOWLEDGEMENTS}

Thanks are due to Siep Massalt for photography, to Paul van Snippenburg for artwork and to Regina van den Brink and Truus van de Hoef for text editing.

\section{LITERATURE CITED}

ASHIHARA H., FUJIMURA T., KOMAMINE A., 1981. Pyrimidine nucleotide biosynthesis during somatic embryogenesis in a carrot suspension culture. Z. Pflanzenphysiol. 104: 129-137

BERTRAND-GARCIA R., WALLING L.L., MURASHIGE T., 1992. Analysis of polypeptides associated with shoot formation in tobacco callus cultures. Amer. J. Bot. 79: 481-487

BIMAL R., SCHEL J.H.N., TAVOLETTI S., WILLEMSE M.T.M., 1995. Localization of poly(A)+containing RNA during female gametophyte development in Medicago sativa and the diploid mutant Medicago sativa spp. falcata using digoxigenin-labelled oligo-dT probes. Sex. Plant Reprod. 8: 18-26

CHANDRA SEKHAR K.N., WILLIAMS E.G., 1992. Non-radioactive in situ localization of poly(A)+RNA during pollen development in anthers of tobacco (Nicotiana tabacum L.). Protoplasma 169: 2-17

CHEN L.J., LUTHE D.S., 1987. Analysis of proteins from embryogenic and non-embryogenic rice (Oryza sativa L.) calli. Plant Sci. 48: 181-188

CHU C.C., WANG C.C., SUN C.S., HSU C., YIN K.C., CHIU C.Y., BI F.Y., 1975. Establishment of an efficient medium for anther culture of rice through comparative experiments on the nitrogen sources. Sci. Sin. 18: 659-668

DE JONG, A.J., SCHMIDT E.D.L., DE VRIES S.C., 1993. Early events in higher-plant embryogenesis. Plant Mol. Biol. 22: 367-377

FRANSZ P.F., KIEFT H., SCHEL J.H.N., 1990. Cell cycle changes during callus initiation from cultured maize embryos. An autoradiographic study. Acta Bot. Neerl. 39: 65-73
FRANSZ P.F., SCHEL J.H.N., 1991A. Cytodifferentiation during the development of friable embryogenic callus of maize (Zea mays). Can. J. Bot. 69: 26-33

FRANSZ P.F., SCHEL J.H.N., 1991B. An ultrastructural study on the early development of Zea mays L. somatic embryos. Can. J. Bot. 69: $858-865$

FUJIMURA T.A., KOMAMINE A., MATSUMOTO H., 1980. Aspects of DNA, RNA and protein synthesis during somatic embryogenesis in a carrot suspension culture. Physiol. Plant. 49: 255260

KAMALAY J.C., GOLDBERG R.B., 1980. Regulation of structural gene expression in tobacco. Cell 19: 935-946

MONTAGUE M.J., KOPPENBRINK J.W., JAWORSKI E.G., 1978. Polyamine metabolism in embryogenic cells of Daucus carota. I. Changes in intracellular content and rates of synthesis. Plant Physiol. 62: 430-433

RAGHAVAN V., 1981. Distribution of poly(A)-containing RNA during normal pollen development and during induced pollen embryogenesis in Hyoscyamus niger. J. Cell Biol. 89: 593-606

SENGUPTA C., RAGHAVAN V., 1980. Somatic embryogenesis in carrot cell suspension. I. Pattern of protein and nucleic acid sy'nthesis. J. Exp. Bot. 31: 259-268.

STERK P., BOOIJ H., SCHELLEKENS, G.A., VAN KAMMEN A., DE VRIES S.C., 1991. Cell- specific expression of the carrot EP2 lipid transfer protein gene. Plant Cell 3: 907-921

STIRN S., JACOBSEN H.J., 1987. Marker proteins for embryogenic differentiation patterns in pea callus. Plant Cell Rep. 6: 50-54

SUNG Z.R., LAZAR G.B., DUDITS D., 1981. Cycloheximide resistance in carrot culture: a differentiated function. Plant Physiol. 68: 261-264

SUNG Z.R., OKIMOTO R., 1981. Embryonic proteins in somatic embryos of carrot. Proc. Natl. Acad. Sci. USA 78: 3683-3687

SUNG Z.R., OKIMOTO R., 1983. Coordinate gene regulation during somatic embryogenesis in carrots. Proc. Natl. Acad. Sci. USA 80: 2661-2665

WILDE H.D., NELSON W.S., BOOIJ H., DE VRIES S.C., THOMAS T.L., 1988. Gene-expression programs in embryogenic and non-embryogenic carrot cultures. Planta 176: 205-211

WURTELE E.S., WANG H., DURGERIAN S., NIKOLAU B.J., ULRICH T.H., 1993. Characterization of a gene that is expressed early in somatic embryogenesis of Daucus carota. Plant Physiol. 102: 303-312

ZIMMERMAN J.L., 1993. Somatic embryogenesis: a model for early development in higher plants. Plant Cell 5: 1411-1423

\author{
ROZMIESZCZENIE POLY(A) + RNA ANALIZOWANE \\ Z UŻYCIEM DIGOXIGENATED OLIGO-dT SONDY \\ PODCZAS SOMATYCZNEJ EMBRIOGENEZY KUKURYDZY
}

\section{STRESZCZENIE}

$\mathrm{Z}$ pomocą sondy oligo-dT znakowanej digoxygeniną lokalizowano mRNA z poly(A) w inicjującym się kalusie i somatycznych zarodkach rozwijających się z silnie embriogennej (A188) i słabo embriogennej (A632) linii kukurydzy. W obu liniach znakowanie zwiększało się stopniowo i preferencyjnie do 4 dnia hodowli. W kalusie linii A188 powstały somatyczne zarodki. Globularne zarodki wykazywały słabsze znakowanie niż kalus. W kalusie A188 w późniejszym stadium widoczne były: górna warstwa embriogeniczna i dolna nieembriogeniczna. Warstwy wyraźnie różniły się intensywnością znakowania.

W późnoglobularnym stadium sygnały poly $(\mathrm{A})+\mathrm{RNA}$ były widoczne na całym zarodku ale na połączeniu $\mathrm{z}$ suspensorem i na tkance kalusowej znakowanie nie było widoczne. 